\title{
A pastoral evaluation on the issue of 'vat en sit' with special reference to the Black Reformed Churches of South Africa
}

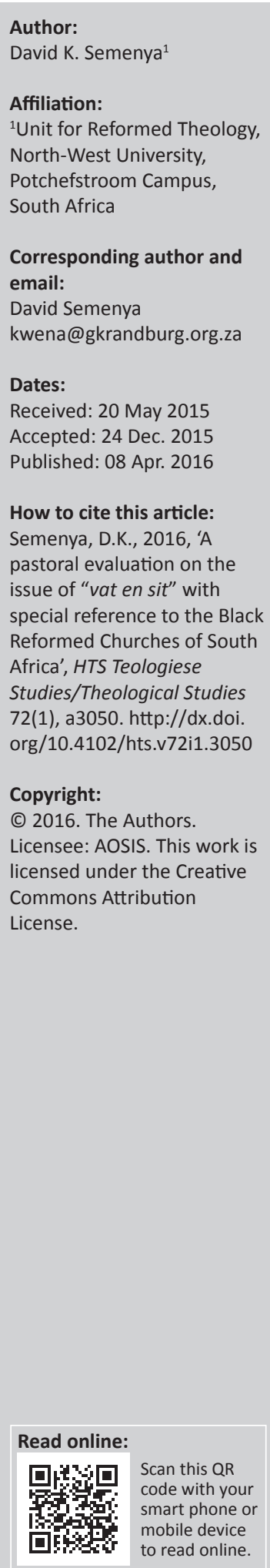

This article investigates the practice of vat en sit to offer solutions to church councils of the mainly Black Reformed Churches in South Africa and also to the couples and families involved in such a relationship. Vat en sit is fast becoming a common phenomenon in South Africa. It should be noted that some of the couples in the vat-en-sit relationships may enter into it with no formal agreement. However, there are partners who may enter into this kind of relationship through a universal partnership agreement whereby the couple plan to live together without marrying one another or a domestic life-partnership agreement whereby the couple opt to regulate their rights and duties in a vat-en-sit relationship. It does not, however, affect only the black members of the Reformed Churches in South Africa but also the family structures of society. The article thus endeavours to determine the reasons why many couples go this route and also how church councils could be assisted in dealing with the issue of vat en sit. This concept will be disseminated under the following headings: (1) The causes of vat en sit relationships (2) Implications of vat en sit (3) The effect of a vat-en-sit relationship in the church (4) The solution to the issue of vat en sit is to assist church councils, couples and their immediate and extended families.

\section{Introduction}

Vat en sit ${ }^{1}$ is a phenomenon in South Africa that occurs as frequently as in other countries in the world like the United States of America. Preller (2011a) speaks of the rising trend in cohabitation reflected in South African statistics. Somewhat conservative statistics indicate a quite large number of domestic partnerships in South Africa. The 1996 census recorded 1268964 people describing themselves as part of such a partnership whilst the 2001 census estimated that nearly 2.4 million individuals were living in domestic partnerships - virtually double the number of 1996.

Preller's (2011a) findings bolster the argument that this is a shift in family structure that most countries and churches, which are used to the traditional marriage household structure, experience.

Manning, Longmore and Giordano (2007:564) suggest that the increase in cohabitation has been fuelled in part by the growing acceptance of cohabitation. This acceptance, however, leaves much to be desired. It would be reasonable to infer that local churches are also challenged by this new phenomenon, given the fact that their members are part of the community.

The question then becomes how churches can address the issue of vat en sit in their own situation and how they may take an informed and relevant stand to this growing trend in the community in which their members live.

\section{Causes of vat en sit}

There are many reasons for the increase in vat en sit, but some of the most prominent are the following: the South African Civil Union Act, Act 17 of 2006 (South Africa 2006), the effect of failed relationships, Mahadi, the modern-day lifestyle as well as the advantages and disadvantages to vat en sit. Each of these demands further exploration.

1.Vat en sit is an Afrikaans phrase that refers to cohabitation. Vat en sit is, however, not a literal translation of cohabitation and, hence, black South Africans prefer the Afrikaans term over the English 'cohabitation'. The terms will be used interchangeably so as to make the article more understandable and readable to the ordinary reader. [What do you mean by an ordinary reader? Your readers would all be academics or ministers.] 


\section{The South African Civil Union Act, Act 17 of 2006}

Even though the law does not explicitly encourage vat en sit, it does create room for couples to enter into civil partnership, which has become an appealing option for cohabiters.

Preller (2011b) explains that the South African Civil Union Act, Act 17 of 2006 (South Africa 2006) enables a couple (irrespective of gender) involved in a monogamous relationship to enter into a legal partnership with each other rather than marriage. The legislation attempts to create a mechanism for couples who do not wish to marry but who nevertheless wish to ensure that their relationship has legal recognition. A civil partnership provides an alternative to those who view marriage as an oppressive institution, marked by rigid gender roles and expectations, by providing couples with a means to establish the social meaning of their relationship.

\section{The effects of failed relationships}

Another contributing factor towards cohabitation or vat en sit, as Harms (2000:1-3) indicates, is the impact of failed previous relationships.

Bear in mind that even though marriage is regarded as a formal structure and moreover instituted by God, it does have its own challenges and weaknesses. Abuse is but one difficulty that could rob marriage of the joy that God intended for both parties. That is not to say that abuse does not occur in a vat en sit relationship, but it may well be that people simply take the route, because marriage or vat en sit, might be the most comfortable option and best suited to them.

Stanley, Rhoades and Markman (2006:500) point out the unfortunate reality that the marriages of couples who chose to first cohabitate have consistently demonstrated a poorer quality of marital communication, lower marital satisfaction and a greater probability of divorce. This raises the question of whether there is some aspect to the experience of cohabitation that increases the risk of a marriage failing. An article by Rodriguez (1998:4) seems to confirm that marriages in which at least one spouse is an ex-cohabiter are 50\% more likely to end in divorce than are marriages in which neither spouse experienced premarital cohabitation. This reflects how failed marriages and relationships are also contributing factors of vat en sit.

\section{Mahadi}

Mahadi ${ }^{2}$ is a significant contributing factor leading to vat en sit, as Semenya (2014:5) indicates, because parents very often place such a high bride price on their daughter that it discourages many men from marrying their dearly beloved lady.

2.Mahadi is a Sotho word for bride price. It is also called Magadi in Pedi and Tswana but is more commonly known by its Zulu name of lobola.
Vat en sit cannot, however, be described as a cultural phenomenon, since it also occurs in cultures where bride price is not a part of the marriage ritual. Since vat en sit is common to most cultures, it is important to gain a clearer picture of the issues at stake.

\section{Today's lifestyle}

Times change and so also the way people live. There are, therefore, many aspects of life that move with the times and, in turn, influence human behaviour.

Amongst the factors that heighten the instance of vat en sit is, firstly, the level of sexual content the youth is exposed to through the media (Mashau 2011:6-7), especially social networks. These networks have become hugely popular in South Africa over the past three decades. Social networks are not necessarily a bad thing in itself, as Mashau (2011:6-7) says, but it is easily misused in one way or the other.

Mashau (2011:6-7) also mentions the role that peer pressure plays in the prevalence of vat en sit relationships in which the youth often feels the need to conform to the practices of others. Another trend going around in this country is the youth's desire to experiment with sex before marriage.

\section{Implications of vat en sit Advantages of vat en sit}

Harms (2000:1-3) avers that, although cohabitation has its disadvantages, there are couples who cohabit with the intention to marry at some point (pre-marital cohabitation). Many others, however, do so with no thoughts of getting married.

This could be ascribed to the fact that, whilst cohabitation is also subject to many of the institutional rules of legal marriage, not all of these rules apply to cohabiters (Baxter 2001:17-18). Baxter (2001:17-18) adds that the 'incompleteness' of these rules may leave space for cohabiting couples to negotiate more egalitarian relationships than is the case in conventional marriages. There are a number of reasons, according to Baxter (2001:17-18), why cohabiting couples may have more equal domestic labour arrangements than married couples. In as far as cohabiting couples reject marriage as an institution, it may be that they also explicitly reject the roles of breadwinner and housewife that accompany traditional marriage.

The other advantage of vat en sit is the ease with which any or both of the parties can walk away from the relationship without having to suffer the legal implications associated with obtaining a divorce.

Furthermore, there is the advantage, as Macalino (2012) indicates, of couples getting to know each other before they make a lifetime commitment unlike those who commit themselves legally to another before truly knowing that person. Macalino (2012) furthermore claims that vat en sit 
affords couples the opportunity to test their sexual attraction and compatibility that they may resolve any problems before marriage, if need be.

\section{Disadvantages of vat en sit}

Stange (2012) argues that, regardless of the advantages or disadvantages to vat en sit, it is here to stay even though couples who live together before marriage are likely to have less committed marriages and tend to become dissatisfied more easily, which may well lead to a divorce.

Cohabiters are often also financially less secure than married couples who usually manage their expenses together (cf. Larson 2001) whilst such matters are separated in vat en sit relationships. It not only affects the economic status of their relationship, but it also means that their responsibility to their children is more loosely maintained.

Although the South African Civil Union Act, Act 17 of 2006 (South Africa 2006) provides couples who enter into civil partnership with certain rights, as set out in a mutually agreed contract, Smith and Robinson (2010:44) indicate that these rights do not compare with those afforded to married couples.

Schoeman (2010:1-3) remarks that cohabitation relationships, whether they be heterosexual or homosexual, may well involve the same core sentimental ideas and reciprocal duties of support that a marriage does, but without the marriage certificate to prove its existence, participants do not have the automatic legal protection that marriages do. A relationship of this nature does not merely involve personal commitment and emotional investment, but it also has a range of legal and proprietary consequences that, if not recorded in writing (partnership agreement), can leave couples in dire straits upon its termination.

From my own point of view, it could be added that a marriage certificate is not a priority for many married couples anyway, and most black South Africans do not bother to register their marriage or convert their marriage into a civil partnership, given that the mahadi or bride price confirms that the marriage is valid. Traditional marriages must be registered just like customary ones, and black married couples thus enjoy the exact same benefits and legal protection. The law views traditional marriages as cohabitation.

Preller (2011b) raises a crucial point, in warning, to the many who believe that simply living together with another person for a continuous period of time or that having children establishes legal rights and duties between them. There is in fact no legal recognition of domestic partnerships. Matshe (2000-2015), however, remarks as follows:

In the current constitutional dispensation in South Africa, it is unlikely that a partner be left in despair taking into account the Domestic Partnerships Bill. While Cohabitation is prevalent the common law effect thereto will now be subject to the Constitution and relevant statutory laws. (s.p.)

Matshe (2000-2015) is absolutely correct that this would be the case if a couple entered into the universal agreement or domestic-partnership contract as stated in the South African Civil Union Act, Act 17 of 2006 (South Africa 2006).

According to the director of the Tshwaranang Legal Advocacy Centre, South African law does not recognise any noncontractual partnership apart from marriage (Gerntholtz 2006), and there is thus no reciprocal duty of support between partners. Spouses cannot claim maintenance when the relationship ends; have no claim against the property of their partner, even if they contributed to its purchase and upkeep and have no claim against the estate of their partner if there is no will. Whoever leaves the partnership walks out with nothing. Harms (2000:1-3) cites the research of Linda Waite on cohabitation as evidence that the cohabiters have no legal, supervisory or custodial rights or responsibilities regarding the children of their partners.

This is not quite the case within black society where matters vary slightly from the findings of Preller (2011b), Gerntholtz (2006) and Harms (2000:1-3). Within the black communities, cohabiters do indeed have supervisory or custodial rights and responsibilities regarding the children of their partners. This is most visible in traditional rituals related to children and also the naming of the children. Such couples are just as involved as any other even when it comes to the lobola negotiations of their children.

\section{Vat en sit in the church}

Pamela J. Smock, a research professor at the Population Studies Centre of the University of Michigan in Ann Arbor, confirms that cohabitation is increasingly becoming the first co-residential union formed amongst young adults (Baklinski 2010).

This seems to also be the case in South Africa since STATS SA recorded the number of cohabiters at more than two million (cf. Preller 2011a), which has naturally resulted in an increase of the number of children born to unmarried cohabiting parents. It has left the church with no option but to seek ways to address vat en sit. The question, in terms of contemporary sexual ethics, then becomes whether the church should acknowledge unmarried long-term relationships and under which circumstances it should do so (Körtner 2008:213).

Experience has taught that the black Reformed churches deem cohabitation and having children out of wedlock as a public sin, and such members are suspended from participating in the sacraments. They are only readmitted to participation once they have undergone catechism directly aimed at explaining the sinfulness of cohabitation and sex outside of marriage. However, readmission tends to turn into a mere formality, however, given that the majority of these couples continue to live together as before. 
Members are readmitted to participate in the sacraments if the church council believe they have repented of their sin and feel that they have been in catechism for long enough. This, however, varies from one local church to another since suspension from participating in the sacraments of inter alia partaking in the Lord's Supper and baptism could last anywhere from three months to even a year or more.

The church is clearly affected by the issue of vat en sit, which necessitates finding a way to address this phenomenon.

\section{The solution to vat en sit in the church}

The declining confidence in religious and social institutions to provide guidance is one of the factors that contribute to the increase in cohabitation (Scott \& Warren 2007:107), which seems to suggest that the church and other social institutions (such as family institutions) could play a significant role in bringing about a solution to this phenomenon. The following recommendations may aid church councils, couples in vat-ensit relationships as well as their immediate and extended families in resolving this issue.

The Bible may not explicitly denounce vat en sit, but that does not mean that God approves of it. God ordained marriage as the lawful institution into which his children may enter and enjoy his blessings. It would, therefore, be a great contradiction to claim that God accepts vat en sit.

Vat en sit leads to the temptation of premarital sex, a sin before God (cf. Ex 22:16; Dt 22:23-24), revealed in the laws set out in Deuteronomy and Exodus that describe the importance of marriage. Couples who wish to marry are obliged to seek counselling from their reverend to gain an understanding of God's will for their relationship and their conduct leading up to married life (cf. 1 Cor 7:2-9, 6:13; Gl 5:19). The Greek word translation for the words 'sexual immorality' or 'fornication' in these verses is porneia (from which we get the English word pornography). In these contexts, it can also be translated as unlawful lust.

The word porneia in the New Testament indeed has a variety of different applications, as Leineweber (2008:14-15) indicates, because the word itself does not have a precise meaning. It is a word that can be used to describe sexual immorality, adultery, pornography, et cetera. The advice that should thus be given to couples who cohabitate is to marry one another.

Paul teaches marriage as the solution to porneia in 1 Corinthians 7:2-9. These verses clearly juxtapose marriage and porneia against each other with the one being licit and the other illicit. This leads to the conclusion that there is just no place for vat en sit (cf. Leineweber 2008:15-16).

Just like Hough (2015) maintains, God never intended for sexuality to be used for any kind of immoral behaviour (cf. 1 Cor 6:13) and refers to Galatians 5:19, which describes porneia as the work of the flesh. Believers either walk in the Spirit or indulge in the flesh, but they cannot do both, and indulging in the flesh will undoubtedly invite the wrath of God.

In terms of the claim that a high bride price contribute to the prevalence of cohabitation, the church council in particular should admonish its members to guard against any cultural practice impeding on marriage. It should be noted that the payment of a dowry or bride price has been a practice in both the Old and New Testaments. However, there are no examples in the Bible where God approves of it when it impedes the institution of marriage. Therefore, members need to understand that marriage is an institution from God and not a cultural custom devised by humans for their own benefit.

The church should take the opportunity during all church activities to convey all Scripture that is denouncing sexual immorality to members from a young age so that they may learn that living an immoral life is wrong in the eyes of the Lord (cf. 1 Cor 6:19). God's Word in Hebrews 13:4 commands everyone to honour the institution of marriage. As Oyebowale (2012:209) says, marriage is to be considered holy, and enjoying its benefits without recognising its holiness simply degrades the holiness. Marriage is not a temporary agreement of convenience. It is an institution of God.

Clarke (1998:178) explains how Hebrews 13:4 denounces the disregard of marriage as a consequence of imperfection thinking and encourages the honouring of marriage as institution of God. Though this text was originally directed at the so-called Essene group of that time, it could just as easily serve as warning to anyone who chooses to engage in a vat-en-sit relationship in which some go to great lengths to avoid marriage by entering into civil partnerships.

Teaching from the Scriptures that to denounce sexual immorality will also be a way for the church to raise awareness about the dangers of abusing social networks, peer pressure and experimenting with sex that could put their lives at risk.

As much as it is the responsibility of the church of God to inform its members about vat en sit, it is also the responsibility of parents to intensively instruct their children in the Word of God and specifically how God renounces vat en sit (cf. Dt 11:18-20; Pr 22:6). The most valuable way would be, of course, for them to live by example and not engage themselves in a vat-en-sit relationship.

\section{Conclusion}

It is abundantly clear that vat en sit is gradually changing family structures in society. The church is under great pressure to address this matter amongst its members.

Whilst the Bible does not explicitly denounce vat en sit, it distinctly indicates that God in no way condones this kind of relationship. It is important to note that vat en sit is also criticised 
in a number of cultures, and in African culture, cohabitation is prohibited until such time that lobola negotiations are complete. If addressing the issue of vat en sit is not made a priority in the lives of Black Reformed church members and also in the community in which they live, real damage will be done to the family structures of future generations.

The church of God needs to take into consideration the solutions offered in this article in order to address vat en sit. In that way, members of Black Reformed churches will live in honour and glory to the Lord and also build a society that glorifies and worships the Lord.

\section{Acknowledgements Competing interests}

The author declares that he has no financial or personal relationships which may have inappropriately influenced him in writing this article.

\section{References}

Baklinski, T.M., 2010, Study: Cohabitation linked to exponential increase in relationship failure risk, viewed 15 January 2015, from https://www.lifesitenews.com/news/ study-cohabitation-linked-to-exponential-increase-in-relationship-failure

Baxter, J., 2001, 'Marital status and the division of household labour: Marriage vs cohabitation', Family Matters 58(Autumn), 16-21.

Clarke, A., 1998, Clarke's commentary: Hebrews-revelation, viewed 11 November 2015, from http://www.enterhisrest.org/history/ac-he-re.pdf

Gerntholtz, L., 2006, An end to vat en sit, viewed 4 December 2014, from http://mg. co.za/article/2006-10-31-an-end-to-vat-en-sit

Harms, W., 2000, 'Research looks at cohabitation's negative effects', The University of Chicago Chronicle 19(11), 1-3, viewed 18 April 2014, from http://chronicle. uchicago.edu/000302/cohabit.shtml

Hough, C., 2015, Counselling for pornography addiction, viewed 11 November 2015 from $h t t p: / /$ therenewedchurch.com/wp-content/uploads/2015/03/Counselingpornography-Addiction.pdf

Körtner, U.H.J., 2008, 'Sexuality and partnership: Aspects of theological ethics in the field of marriage, unmarried and homosexual couples', HTS Theological Studies 64(1), 209-225. http://dx.doi.org/10.4102/hts.v64i1.18
Larson, J.H., 2001, The verdict on cohabitation vs marriage, viewed 5 November 2015 from http://marriageandfamilies.byu.edu/issues/2001/January/cohabitation.htm

Leineweber, P.R., 2008, The Greek word porneia in the Matthean exception clause, viewed 11 November 2015, from http://digitalcommons.liberty.edu/ honors $/ 60 /$

Macalino, M.L., 2012, 5 reasons you shouldn't say "I do" without living together first viewed 3 November 2015, from http://www.yourtango.com/2012128381/5reasons-you-should-live-together-getting-married

Manning, W.D., Longmore, M.A. \& Giordano, P.C., 2007, 'The changing institution of marriage: Adolescents' expectations to cohabit and to marry', Journal of Marriage and Family 69(3), 559-575.

Mashau, T.D., 2011, 'Cohabitation and premarital sex amongst Christian youth in South Africa today: A missional reflection', HTS Teologiese Studies/Theological Studies 67(2), Art. \#899, 7 pages. http://dx.doi.org/10.4102/hts.v67i2.899

Matshe, L., 2000-2015, Cohabitation, concubinage, or domestic partnership: You and your rights, viewed 10 November 2015, from http://www.legalcity.net/Index. $\mathrm{cfm}$ ?fuseaction=Rights.article\&ArticleID=9907616

Oyebowale, M.O., 2012, 'Sanctity of sex in Christian marriage: An exegetical study of Hebrews 13:4 and its relevance to Nigeria', Ilorin Journal of Sociology 4(1) 207-222.

Preller, B., 2011a, Cohabitation law in South Africa: If you don't have an agreement you may leave with nothing, viewed 14 May 2015, from https://divorceattorneys. wordpress.comcohabitation-law-in-south-africa

Preller, B., 2011b, Cohabitation and domestic partnerships in South Africa, viewed 5 January 2014, from https://www.edivorce.co.za/cohabitation-and-domesticpartnerships-in-south-africa

Rodriguez, H., 1998, Cohabitation: A snapshot, viewed 24 May 2014, from info@ clasp.org

Schoeman, N., 2010, Marriage vs cohabitation (life partnerships), viewed 13 June 2014, from https://www.schoeman.co.za/marriagesvscohabitation

Scott, K. \& Warren, M., 2007, Perspective on marriage, Oxford University Press, New York.

Semenya, D.K., 2014, 'The practical guidelines on the impact of mahadi [bride price] on the young Basotho couples prior to marriage', HTS Theological Studies 70(3), 1-6. http://dx.doi.org/10.4102/hts.v70i3.1362

Smith, B.S. \& Robinson, J.A., 2010, 'An embarrassment of riches or a profusion of confusion?: An evaluation of the continued existence of the Civil Union Act 17 of 2006 in the light of prospective domestic partnership legislation in South Africa', Potchefstroomse Elektroniese Regsblad/Potchefstroom Electronic Law Journal 13(2), 30-204.

South Africa, 2006, Civil Union Act. 2006, (Act No. 17 of 2006). To Provide for the solemnisation of Civil Union, by way of either a Marriage or Civil Partnership; The Legal consequences of Civil Unions, and to provide for matters incidental thereto. (Government notice no. 29441). Government gazette 497, 17 November.

Stange, C.K., 2012, The disadvantages of cohabitation before marriage, viewed 05 November 2015, from http://familylawheadquarters.com/2012/09/10/thedisadvantages-of-cohabitation-before-marriage

Stanley, S.M., Rhoades, G.K. \& Markman, H.J., 2006, 'Sliding versus deciding: Inertia and the premarital cohabitation effect', Family Relations 55(4), 499-509. 